Dept. of Forensic Medicine and Toxicology,

Faculty of Veterinary Medicine, Beni-Sueif University

\title{
TOXIC INTERACTION OF PYRETHROID (KATRON) AND SODIUM FLUORIDE ON REPRODUCTIVE PERFORMANCE OF MALE ALBINO RATS
}

(With 3 Tables and 7 Figures)

By

\section{MANAL SH. HUSSEIN; KH.A. ABDOU; A.SH. MAHMOUD* and WALAA ABD-EL-RAHAMAN}

* Dept. of Forensic Medicine and Toxicology, Faculty of Veterinary Medicine, Assiut University (Received at 9/9/2008)

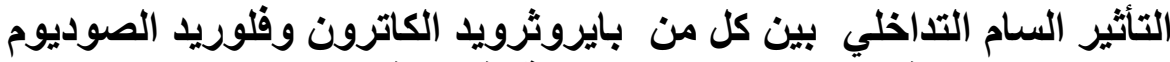

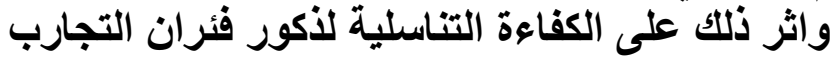

منال شعراوى حسين ، خالد عباس حلهي ، عادل شحاتة محمود ،

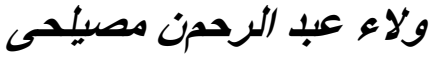

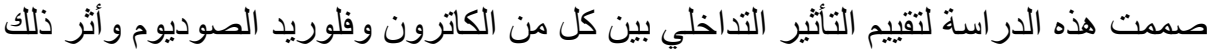

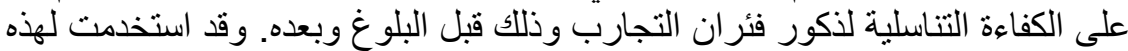

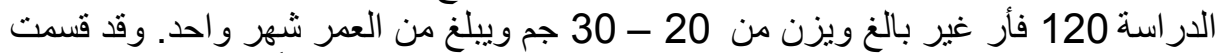

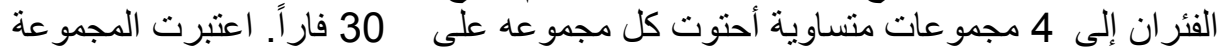

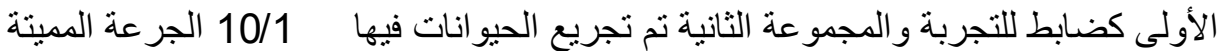

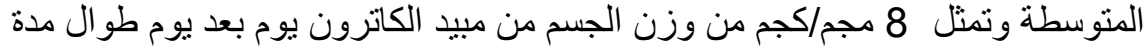

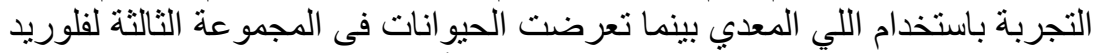

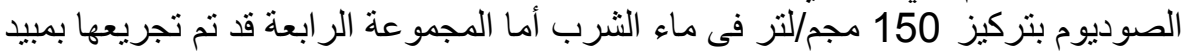

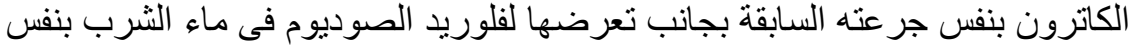

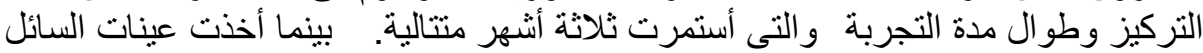

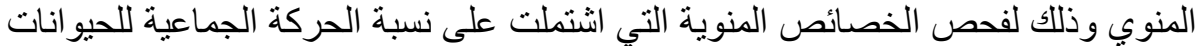

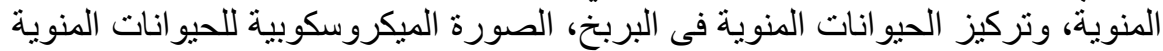

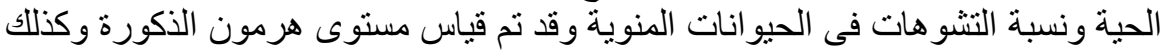

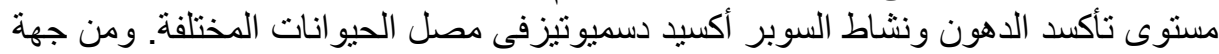

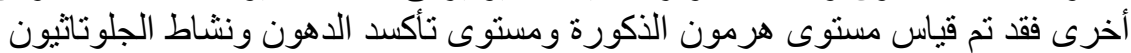

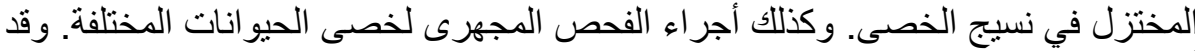

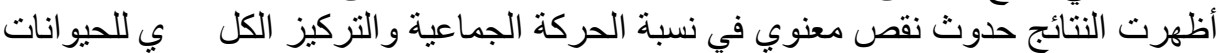

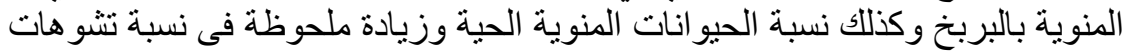

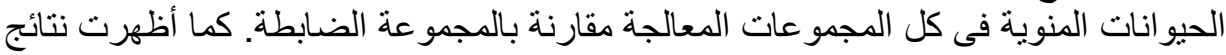

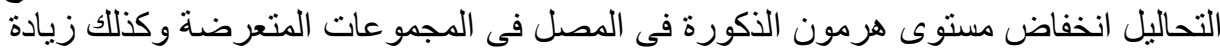


معنوية فى مستوى تأكسد الدهون ونقص شديد فى نشاط إنزيم السوبر أكسيد ديسميوتيز في

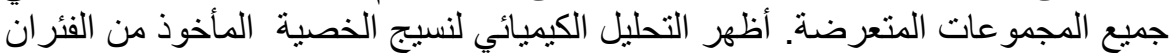

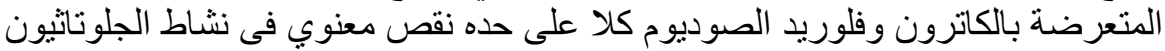

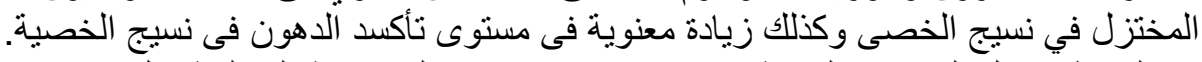

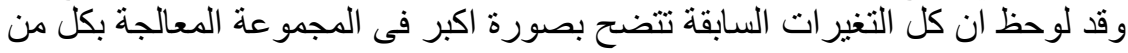

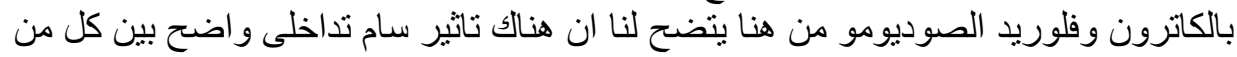

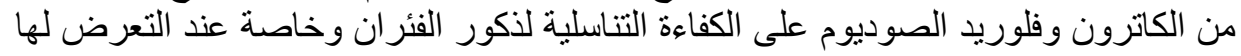

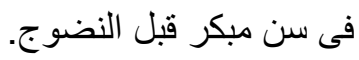

\section{SUMMARY}

The present study aimed to investigate the effect of synthetic pyrethroid (katron) and fluoride on the reproductive activities of male albino rats. One hundred and twenty apparently healthy immature male albino rats with initial weigh 20-30 grams and 30 days old were divided into four groups (30 rat/group), group I remained untreated and served as negative control group, group II were received Katron (pyrethroid insecticide) in doses of $1 / 10$ of LD50 (8 mg/kg, b.wt.) orally by using stomach gavage day after day along the period of experiment (for 12 weeks), group III were administered sodium fluoride (NaF) in drinking water in a dose of $150 \mathrm{mg} / \mathrm{Liter}$, group IV were received both Katron and sodium fluoride in the same doses and manner as in group II and III. Complete sperm picture, testosterone concentration, lipid peroxide levels and superoxide dismutase activity in serum, also testosterone concentration, lipid peroxide levels and glutathione reduced activity in testicular homogenate and histopathological changes in testes were examined to evaluate the reproductive efficiency of the treated male rat. Significant decrease in sperm motility\%, sperm cell concentration, live sperm $\%$, serum testosterone concentration, and serum superoxide dismutase activity were recorded. Also, decrease in testicular concentration of testosterone and glutathione reduced activity and significant increase in total sperm abnormalities percentage and lipid peroxide levels in both serum and testicular homogenate were noticed. All the pervious changes are seen in the all treated groups but they are marked and obvious in the fourth group (treated with both katron and sodium fluoride). In conclusion there are an obvious toxic interaction between pyrethroid and fluoride on the reproductive efficiency of the treated male rats especially when the exposure begin in young ages before maturity.

Key words: Pyrethroid, sodium fluoride, albino rats, reproductive activity, toxicity. 


\section{INTRODUCTION}

Environmental pollution is one of the major problems affecting health officials everywhere, particularly in an expanding industrial economy.

Principal stationary pollution sources include chemical plants, coal-fired power plants, oil refineries, nuclear waste disposal activities, incinerators, large animal farms, metals production factories, plastic factories and super phosphate factories. The heavly use of pesticides, fertilizers, as well as growth hormones in agriculture are main sources of environmintal pollutants.

Pollutants even at low concentration show significant biological effects, they diffuse readily in air and water, having tendency to accumulate in living tissues and persistent in nature, also in breakdown of combination product, showing persistence in toxicity (Farzana, 2004).

Exposure to environmental pollutants is often not limited to a single chemical but the probabilities of exposures to two or more compounds are high. Heavy metals and pesticides are between the most important pollutants which induce hazardous effects among human and animals.

The exposure to two chemicals at the same time will produce a response that may be simple additive of their individual response or may be greater or less than that expected by addition of their individual responses. Study of these interactions often leads to better understanding of the mechanism of action of the chemical involved (Doull et al., 1980)

Actually in the environment we detect high percentage of fluoride in water (Salem et al., 2001), in addition to the massive use of pesticide especially pyrethroid insecticides.Concerning the continuous presence of these pollutants in our environment and continuous exposure of animals to them from birth till death, so the aim of the present study is to investigate the hazardous effects of both fluoride and pyrethroids (Lambada cyhalothrine) on the reproductive activities of immature male albino rats

\section{MATERIALS and METHODS}

\section{1- Tested compounds:}

\section{1. a Katron (Lambada cyhalothrin $25 \%$ )}

It is a synthetic pyrethroid insecticide, available as emulsifiable concentrate, containing active ingredient in a concentration of $2.5 \%$, obtained from Agrochemical Company, Alex. 


\section{1. b Sodium fluoride (NaF)}

White powder, odorless, easily soluble in water obtained from Sigma company.

\section{2- Experimental animals}

One hundred and twenty apparently healthy immature male albino rats with initial weigh 20-30 grams and 30 days old, were supplied from the breeding unit of the Egyptian organization for the biological vaccine production. Animals were left for one week before the start of the experiment for acclimatization. They were fed in well balanced commercial rat diet with free access to food and water.

Experimental rat were classified into four equal groups (30) in each. The first groups a control negative group where the animals were left without any treatment along the whole period of experiment. The second group, rats in this group were orally intubated Katron $25 \%$ in dose level of $8 \mathrm{mg} / \mathrm{kg}$.bw. equivalent to $1 / 10 \mathrm{LD} 50$ (WHO, 1990). The third group, animals in this group exposed to sodium fluoride $(\mathrm{NaF})$ in drinking water in a concentration of $150 \mathrm{mg} / \mathrm{Liter}$, as described by (Zhu, et al., 2000). The fourth group was treated with katron and sodium fluoride in drinking. The tested substances were administered day after day and the experiment lasted for three successive months.

\section{Sampling:}

Five animals from each experimental group were taken and the blood sample were collected from the orbital venous plexus .Blood sample were collected into plain centrifuge tubes and used for serum collection; the collected sera were used for determination of serum biochemical parameters (lipid peroxide, superoxide dismutase and testosterone). These animals were scarified and semen samples were collected by maceration of head of the epidydimis and in order to evaluate progressive sperm motility, concentration of sperm cells, the percentage of live and dead sperm and sperm cells abnormalities. Tests samples were collected and classified into two portions, the first one were collected in clean dry plastic bag and kept at $-20^{\circ} \mathrm{c}$ till preparation of tissue homogenate and used for determination of Lipid peroxide level, Glutathione reduced and testosterone hormone activities, the second one was fixed in $10 \%$ neutral formalin and used for histopathological study.

\section{Methods:}

\section{1-Sperm evaluation}

Progressive forward sperm motility, concentration of sperm cells and sperm cells abnormalities were performed according to method of 
Bearden and Fuquay, 1980, while the percentage of live and dead sperm was performed according to Blom, 1950.

\section{2- Determination of some serum biochemical constituents:-}

Total testosterone concentration in serum were determined by using ELISA with special ready made kits as adopted by Voller, et al., 1979. Lipid peroxide levels in serum samples were determined according to Thyer, 1985. While Superoxide dismutase (SOD) activity in serum was carried out according to Misra and Fridouich, 1972.

3- Determination of lipid peroxide levels, glutathione reduced activity and testosterone hormone levels in testicular homogenate:-

Testicular samples were thawed and homogenized using ice cold phosphate buffer ( $\mathrm{pH} 7.4$ ) yielding a 1/10 homogenate, $(0.5$ gm testes + $5 \mathrm{ml}$ phosphate buffer), the homogenate were centrifuged at 3000 r.p.m. for 10 minutes in special cold centrifuge, the supernatant was assayed immediately for LPO and testosterone hormone by the same methods described in serum, in addition to determination of glutathione reduced (GSH) activity after Beutler, et al., 1963.

\section{4- Histopathological examination:}

Histopathological examination of the testes was performed according to the method descriped by Carleton, et al., 1967.

\section{5- Statistical analysis:}

Data were compared across groups using ANOVAone way analysis of variance (Sendecor and Cochran, 1982).

The values marked with same litter (A) are significantly different from group I at $\mathrm{P}<0.05$ and that marked with same litter (a) are significantly different from group I at $\mathrm{P}<0.01$.

The values marked with same litter (B) are significantly different from group II at $\mathrm{P}<0.05$ and that marked with same litter (b) are significantly different from group II at $\mathrm{P}<0.01$.

The values marked with same litter $(C)$ are significantly different from group III at $\mathrm{P}<0.05$ and that marked with same litter (c) are significantly different from group III at $\mathrm{P}<0.01$

\section{RESULTS}

\section{1-Effect on male fertility:}

Effect of katron and sodium fluoride on fertility of treated rats was recorded in Table (1) the obtained data revealed a significant decrease in the mean values of sperm motility percentage in katron treated group (Group I) at $6^{\text {th }}$ and $8^{\text {th }}$ weeks post-exposure and at $6^{\text {th }}$ 
weeks in and sodium fluoride treated group (Group II) in comparison with control group. There was a highly significant decrease in the mean values of sperm motility \% in katron treated group (Group I) at $10^{\text {th }}$ and $12^{\text {th }}$ week post exposure and in sodium fluoride treated group (Group II) at $8^{\text {th }}$ weeks and in both groups at $10^{\text {th }}$ and $12^{\text {th }}$ weeks post-exposure. There is extreme decrease in sperm motility percentage at $8^{\text {th }}, 10^{\text {th }}$ and $12^{\text {th }}$ weeks post-exposure in group IV that received both treated substances when they compare with control group. There is significant difference between (Group IV) and (Group II) at $8^{\text {th }}$ and $12^{\text {th }}$ weeks postexposure.

The recorded results in Table 1 revealed a significant decrease in the mean values of sperm cell concentration in rats treated with Katron at $10^{\text {th }}$ and $12^{\text {th }}$ week and in rats exposed to sodium fluoride at the eighth and $12^{\text {th }}$ weeks. Administration of both Katron and sodium fluoride in (Group IV) induced a significant reduction in sperm cell concentration specially at the $10^{\text {th }}$ and $12^{\text {th }}$ weeks post-exposure.

Administration of katron or sodium fluoride either alone (Groups I, II) or together induced significant decrease in the mean values of live sperm all over the period from $6^{\text {th }}$ to $12^{\text {th }}$ weeks post-exposure (Table, $1)$.

There was a significant difference between (Group IV), (Group II) and (Group III) at the $12^{\text {th }}$ week post-exposure live.

Significant increase was recorded in the sperm abnormality percentage in rats exposed to Katron (Group II) or that received sodium fluoride in drinking water (Group III) all over the experimental period in comparison with control group. The present results revealed that administration of both Katron and sodium fluoride (Group IV) induced a significant increase in sperm abnormality percentage at $6^{\text {th }}$ and $8^{\text {th }}$ weeks post-exposure and extreme increase in sperm abnormality percentage especially at $10^{\text {th }}$ and $12^{\text {th }}$ weeks post-exposure in comparison with control group (Table, 1). Also a significant difference between (Group IV) and (Group III) at the $12^{\text {th }}$ week post-exposure.

\section{2- Biochemical results}

Table, 2 represented the effect of administration of Katron 25\% in dose level of $8 \mathrm{mg} / \mathrm{kg} . \mathrm{bw}$, sodium fluoride $(\mathrm{NaF})$ in drinking water in a concentration of $150 \mathrm{mg} /$ Liter and the two tested compounds on serum Total testosterone level, Lipid peroxide levels and Superoxide dismutase (SOD) activity in male treated rats. Rats that exposed to Katron (Group II) showed a highly significant decrease in the mean values of serum testosterone concentration at the $4^{\text {th }}, 6^{\text {th }}, 8^{\text {th }}$ and $12^{\text {th }}$ weeks post- 
exposure, Rats in group III that received sodium fluoride in drinking water showed significant decrease in the mean values of serum testosterone concentration only at the $6^{\text {th }}$ week of the experiment. A highly significant decrease in the mean values of serum testosterone concentration was recorded in (Group IV) that received both Katron and sodium fluoride at $4^{\text {th }}, 6^{\text {th }}$ and $12^{\text {th }}$ week post exposure in comparison with control group (Table, 2). There was a significant variance between (Group IV) and (Group III) at $4^{\text {th }}$ and $12^{\text {th }}$ weeks post-exposure and between (Group IV) and (Group II) at $4^{\text {th }}$ week only.

No significant changes were recorded in the mean values of LPO concentration in serum in group II that received Katron $(8 \mathrm{mg} / \mathrm{kg}$ body weight by intubation) or group III that administered sodium fluoride $(150 \mathrm{mg} / \mathrm{L}$ in drinking water) along the whole period of the experiment. The obtained results revealed that there was a significant increase in serum LPO only in group IV from the $8^{\text {th }}$ weeks till the end of the experiment (Table, 2). There was a significant difference between (Group IV) and (Group II) at $8^{\text {th }}$ week post-exposure. There was a highly significant decrease in the mean values of (SOD) activity in serum in all exposed rats in (Group II), (Group III) and (Group IV) from $8^{\text {th }}$ to $12^{\text {th }}$ weeks post-exposure (Table, 2).

3- The effect of the tested substances on testosterone hormone concentration, lipid peroxide levels, glutathione reduced activity in testicular homogenate:-

Results presented in Table 3 indicated that the exposure to both Katron and sodium fluoride (Group IV) resulted in significant reduction in the mean values of testosterone concentration in testicular homogenate specially at $4^{\text {th }} 6$ th, $10^{\text {th }}$ and $12^{\text {th }}$ weeks post-exposure. Also there was significant difference between (Group IV) and (Group III) at second, fourth and sixth weeks post-exposure.

Also the statistical analysis of the obtained results revealed that rats treated with two tested compounds Katron and NaF (Group IV) induced a significant increase in the mean values of LPO concentration in testicular homogenate at $2^{\text {nd }}, 4^{\text {th }}$ and $12^{\text {th }}$ weeks of the experiment (Table, 3).

Rats that exposed to Katron (Group II) and that received sodium fluoride (Group III) showed a significant decrease in glutathione reduced (GSH) concentration in testicular homogenate from the $6^{\text {th }}$ week post exposure till the end of experiment.

The present data revealed that there was a significant decrease in (GSH) in testicular homogenate (Group IV) at all over the experimental 
period (Table, 3). There was a significant difference between (Group IV) and (Group II) at $2 \mathrm{nd}, 4^{\text {th }}, 6^{\text {th }}$, and $8^{\text {th }}$ week and between (Group IV) and (Group III) at the $2^{\text {nd }}$ and $4^{\text {th }}$ week post-exposure. Also, a significant variance between (Group II) and (Group III) was recorded at $2^{\text {nd }}, 4^{\text {th }}$ and $6^{\text {th }}$ week post exposure.

\section{4-Histopathological results:}

\section{(a)- Pyrethroid (Katron)}

Early degenerative changes were observed in the most of the spermatogonial cells lining the seminiferous tubules; the basement membrane appeared mildly thickened with normal leydig cells (2 weeks post-exposure) as shown in Fig. 1. Some of the seminiferous tubules showed incomplete spermatogenic process with mild degenerative changes in the spermatogonial cells (4 weeks post-exposure) (Fig. 2). Few numbers of tubules showed degenerative changes with early necrotic changes with incomplete spermatogenic process $(10 \& 12$ weeks post-exposure).

\section{(b)- Sodium fluoride}

Complete spermatogenic process was seen in the most of tubules, few tubules had degenerative changes and appeared free from spermatozoa, Edema was also found in the interstitial tissue with very mild leydig cell proliferation ( $6 \& 8$ weeks post-exposure). Very mild degenerative changes were found in the seminiferous tubules with complete spermatogenic process in the most of the tubules, the blood vessels were congested ( $10 \& 12$ weeks post-exposure) (Fig. 3).

\section{(c)- Exposure to both Katron and sodium fluoride}

Some of the seminiferous tubules showed mild degree of degenerative changes, the interstitial blood vessels were congested and the basement membrane of some tubules was markedly thickened ( 2 weeks post-exposure). Moderate to severe degenerative changes could be observed in a large number of tubules with in- complete spermatogenic process, necrotic changes were also found in others tubules, the basement membrane was thickened and the leydig cells were proliferated (4 \& 6 weeks post-exposure) (Fig. 4\&5). Severe degenerative changes were seen in the seminiferous tubules with incomplete spermatogenic process, the interstitial blood vessels were dilated and congested ( $8 \& 10$ weeks post-exposure) (Fig. 6). Sever degree of degeneration could be seen in a large number of tubules accompanied with incomplete spermatogenic process, some spermatozoa were degenerated and dead (12 weeks post-exposure) (Fig. 7). 
Table 1: Mean values of progressive motility \%, sperm cell concentration $\left(\times 10^{6} / \mathrm{ml}\right)$, live sperm $\%$ and sperm abnormalities $\%$ in treated and control rat groups

\begin{tabular}{|c|c|c|c|c|c|}
\hline $\begin{array}{l}\text { Groups } \rightarrow \\
\text { Time } \\
\text { post-exp. } \downarrow\end{array}$ & Parameters & Control & Katron & $\mathrm{NaF}$ & $\begin{array}{l}\text { Katron } \\
+\mathrm{Na} \mathrm{F}\end{array}$ \\
\hline \multirow{4}{*}{$\begin{array}{c}\text { Six } \\
\text { weeks }\end{array}$} & motility $\%$ & $70 \pm 2$ & $53 \pm 3$ & $57 \pm 4$ & $\begin{array}{ll}53 \pm 3 & \mathrm{~A} \\
\end{array}$ \\
\hline & Sperm cell conc. & $115 \pm 9.8$ & $71 \pm 6.6$ & $110 \pm 17.8$ & $120 \pm 15.9$ \\
\hline & Live sperm \% & $86.8 \pm 1.3$ & $\begin{array}{r}69.6 \pm 1.7 \\
\mathrm{~A}\end{array}$ & $72.2 \pm 2$ & $69 \pm 1.2$ \\
\hline & Sperm abnor. $\%$ & $14.8 \pm 1$ & $\begin{array}{r}26.6 \pm 1.8 \\
\mathrm{~A}\end{array}$ & $27.8 \pm 2$ & $31.6 \pm 1.9$ \\
\hline \multirow{4}{*}{ Eight weeks } & motility \% & $70 \pm 2$ & $54 \pm 5$ & $46 \pm 3.6$ & $41 \pm 5$ \\
\hline & Sperm cell conc. & $189.8 \pm 14.5$ & $139.2 \pm 14.5$ & $\begin{array}{r}120.5 \pm 20 \\
\mathrm{~A}\end{array}$ & $160 \pm 7$ \\
\hline & Live sperm $\%$ & $81.8 \pm 0.9$ & $\begin{array}{r}66.8 \pm 1 \\
\end{array}$ & $70.4 \pm 1.4$ & $\begin{array}{r}66.9 \pm 0.63 \\
\mathrm{a}\end{array}$ \\
\hline & Sperm abnor. \% & $15 \pm 1$ & $40 \pm 2$ & $36.6 \pm 1.3$ & $42.8 \pm 3.5$ \\
\hline \multirow{4}{*}{$\begin{array}{c}\text { Ten } \\
\text { weeks }\end{array}$} & motility $\%$ & $67 \pm 2$ & $48 \pm 5$ & $44 \pm 4$ & $44 \pm 4$ \\
\hline & Sperm cell conc. & $208 \pm 9.3$ & $\begin{array}{r}154.3 \pm 13.7 \\
\mathrm{~A} \\
\end{array}$ & $166.5 \pm 18.2$ & $\begin{array}{r}147.7 \pm 13.4 \\
\mathrm{~A}\end{array}$ \\
\hline & Live sperm $\%$ & $79 \pm 0.84$ & $\begin{array}{r}65.8 \pm 1.7 \\
\mathrm{a} \\
\end{array}$ & $\begin{array}{r}61.6 \pm 0.66 \\
\mathrm{a}\end{array}$ & $\begin{array}{r}63.2 \pm 1.4 \\
\\
\mathrm{a}\end{array}$ \\
\hline & Sperm abnor. $\%$ & $17.9 \pm 0.6$ & $32.2 \pm 2$ & $\begin{array}{r}42.6 \pm 1.8 \\
\text { a B }\end{array}$ & $\begin{array}{rr}42.7 \pm 3 & \\
& \text { a B }\end{array}$ \\
\hline \multirow{4}{*}{$\begin{array}{l}\text { Twelve } \\
\text { week }\end{array}$} & motility \% & $70 \pm 1.5$ & $52 \pm 5$ & $35 \pm 6 \quad$ a B & $26 \pm 6$ \\
\hline & Sperm cell conc. & $170 \pm 11.6$ & $127.2 \pm 20$ & $\begin{array}{r}108 \pm 15.6 \\
\mathrm{~A}\end{array}$ & $\begin{array}{r}104 \pm 13.4 \\
\mathrm{~A}\end{array}$ \\
\hline & Live sperm $\%$ & $81.5 \pm 2$ & $\begin{array}{r}62.8 \pm 0.66 \\
\mathrm{a}\end{array}$ & $62 \pm 0.5$ & $\begin{array}{r}55.1 \pm 0.67 \\
\text { a B C }\end{array}$ \\
\hline & Sperm abnor. \% & $16.8 \pm 2$ & $\begin{array}{r}37.8 \pm 2.6 \\
\\
\end{array}$ & $38.2 \pm 3.6$ & $\begin{array}{r}47.2 \pm 1 \\
\text { a B C }\end{array}$ \\
\hline
\end{tabular}

For progressive motility \% LSD at $\mathrm{P}<0.05$ is 12.376 , at $\mathrm{P}<0.01$ is 17.352

For Sperm cell concentration $\left(\times 10^{6} / \mathrm{ml}\right)$ LSD at $\mathrm{P}<0.05$ is 51.641 , at $\mathrm{P}<0.01$ is 72.401

For Live sperm \% LSD at $\mathrm{P}<0.05$ is 8.514 , at $\mathrm{P}<0.01$ is 11.937

For sperm abnormalities \% LSD at $\mathrm{P}<0.05$ is 8.464 , at $\mathrm{P}<0.01$ is 11.866 
Table 2: Mean values of testosterone concentration $(\mathrm{ng} / \mathrm{ml})$, lipid peroxide concentration $(\mathrm{n} \mathrm{mol} / \mathrm{ml})$ and superoxide dismutase (SOD) activity $(\mathrm{U} / \mathrm{ml})$ in serum of treated and control rat groups

\begin{tabular}{|c|c|c|c|c|c|}
\hline $\begin{array}{l}\text { Groups } \rightarrow \\
\text { Time } \\
\text { Post-exp. } \downarrow\end{array}$ & Parameters & Control & Katron & $\mathrm{NaF}$ & $\begin{array}{l}\text { Katron } \\
+\mathrm{Na} \mathrm{F}\end{array}$ \\
\hline \multirow{3}{*}{$\begin{array}{c}\text { Two } \\
\text { weeks }\end{array}$} & Testosterone conc. & $1.53 \pm 0.4$ & $1.03 \pm 1$ & $1.8 \pm 1$ & 0 \\
\hline & Lipid peroxide conc. & $10.25 \pm 0.7$ & $9.86 \pm 1.5$ & $9.54 \pm 1.3$ & $10.3 \pm 1.4$ \\
\hline & SOD activity & $178.8 \pm 17$ & $212.7 \pm 19$ & $238 \pm 19$ & $245.6 \pm 18$ \\
\hline \multirow{3}{*}{$\begin{array}{c}\text { Four } \\
\text { weeks }\end{array}$} & Testosterone conc. & $8.9 \pm 0.5$ & $\begin{array}{r}1.2 \pm 1 \\
\text { a c }\end{array}$ & $7.4 \pm 2$ & 0 \\
\hline & Lipid peroxide conc. & $6.88 \pm 0.04$ & $6.66 \pm 0.5$ & $5.50 \pm 0.1$ & $6.52 \pm 0.1$ \\
\hline & SOD activity & $181.3 \pm 18$ & $150.2 \pm 16$ & $200.3 \pm 10$ & $157.9 \pm 9$ \\
\hline \multirow{3}{*}{$\begin{array}{c}\text { Six } \\
\text { weeks }\end{array}$} & Testosterone conc. & $9.0 \pm 0.5$ & $1.4 \pm 1$ & $4.2 \pm 2$ & $\begin{array}{r}0.98 \pm 0.4 \\
\text { a }\end{array}$ \\
\hline & Lipid peroxide conc. & $7.43 \pm 0.6$ & $7.23 \pm 0.5$ & $7.00 \pm 0.6$ & $6.90 \pm 0.3$ \\
\hline & SOD activity & $181 \pm 19$ & $121.9 \pm 13$ & $171.8 \pm 4$ & $173.4 \pm 9$ \\
\hline \multirow{3}{*}{$\begin{array}{l}\text { Eight } \\
\text { week }\end{array}$} & Testosterone conc. & $9.8 \pm 2.5$ & $\begin{array}{r}5.6 \pm 0.5 \\
\mathrm{~A}\end{array}$ & $7.4 \pm 1.6$ & $7.4 \pm 0.76$ \\
\hline & Lipid peroxide conc. & $7.50 \pm 0.9$ & $6.59 \pm 0.2$ & $7.95 \pm 1.2$ & $\begin{array}{r}9.30 \pm 1.2 \\
\mathrm{~A} \mathrm{~b}\end{array}$ \\
\hline & SOD activity & $211.7 \pm 7$ & $\begin{array}{r}88.1 \pm 19 \\
\mathrm{~A}\end{array}$ & $\begin{array}{r}100.2 \pm 16 \\
\text { a }\end{array}$ & $85 \pm 4$ \\
\hline \multirow{3}{*}{$\begin{array}{c}\text { Ten } \\
\text { weeks }\end{array}$} & Testosterone conc. & $9.0 \pm 0.7$ & $5.9 \pm 2$ & $8.9 \pm 0.9$ & $6.3 \pm 0.4$ \\
\hline & Lipid peroxide conc. & $6.38 \pm 0.4$ & $8.04 \pm 0.4$ & $7.00 \pm 0.2$ & $\begin{array}{r}8.66 \pm 0.7 \\
A\end{array}$ \\
\hline & SOD activity & $200.2 \pm 19$ & $\begin{array}{r}54.6 \pm 9 \\
\mathrm{~A}\end{array}$ & $\begin{array}{r}82.8 \pm 18 \\
\mathrm{a}\end{array}$ & $\begin{array}{r}43.36 \pm 6 \\
a \\
\end{array}$ \\
\hline \multirow{3}{*}{$\begin{array}{l}\text { Twelve } \\
\text { weeks }\end{array}$} & Testosterone conc. & $11.4 \pm 0.6$ & $\begin{array}{r}7.3 \pm 3 \\
\mathrm{~A}\end{array}$ & $11.0 \pm 1$ & $\begin{array}{r}2.5 \pm 1.6 \\
\text { a B c }\end{array}$ \\
\hline & Lipid peroxide conc. & $6 \pm 0.5$ & $6.00 \pm 0.1$ & $5.66 \pm 0.2$ & $\begin{array}{r}7.90 \pm 0.02 \\
\mathrm{~A} \\
\end{array}$ \\
\hline & SOD activity & $224.4 \pm 6$ & $\begin{array}{r}56.3 \pm 3 \\
\mathrm{~A}\end{array}$ & $\begin{array}{r}70.5 \pm 13 \\
\text { a }\end{array}$ & $\begin{array}{r}46.8 \pm 5 \\
\mathrm{a}\end{array}$ \\
\hline
\end{tabular}

For Testosterone concentration LSD at $\mathrm{P}<0.05$ is 3.866, at $\mathrm{P}<0.01$ is 5.273

For Lipid peroxide concentration LSD at $\mathrm{P}<0.05$ is 1.806 , at $\mathrm{P}<0.01$ is 2.463

For Superoxide dismutase (SOD) activity LSD at $\mathrm{P}<0.05$ is 74.559 , at $\mathrm{P}<0.01$ is 101. 689 
Table 3: Mean values of testosterone concentration (ng/gm tissue), lipid peroxide concentration ( $\mathrm{n} \mathrm{mol} / \mathrm{gm}$ tissue) and glutathione reduced $(\mathrm{GSH})$ concentration ( $\mathrm{m} \mathrm{mol} / \mathrm{gm}$ tissue) in testicular homogenate of treated and control rat groups.

\begin{tabular}{|c|c|c|c|c|c|}
\hline $\begin{array}{l}\text { Groups } \\
\rightarrow \\
\text { Time } \\
\text { Post- } \\
\text { exp. } \downarrow\end{array}$ & Parameters & Control & Katron & $\mathrm{NaF}$ & $\begin{array}{l}\text { Katron } \\
+\mathrm{NaF}\end{array}$ \\
\hline \multirow{3}{*}{$\begin{array}{l}\text { Two } \\
\text { weeks }\end{array}$} & $\begin{array}{l}\text { Testosterone } \\
\text { conc. }\end{array}$ & $\begin{array}{r}1.4 \pm 0.66 \\
\mathrm{c}\end{array}$ & $\begin{array}{r}1.3 \pm 0.8 \\
\mathrm{c}\end{array}$ & $7.3 \pm 1.9$ & $\begin{array}{r}1.6 \pm 0.7 \\
\mathrm{c}\end{array}$ \\
\hline & $\begin{array}{l}\text { Lipid peroxide } \\
\text { conc. }\end{array}$ & $8.9 \pm 2$ & $19.7 \pm 1.2$ & $15 \pm 2$ & $\begin{array}{r}25 \pm 3 \\
\mathrm{~A}\end{array}$ \\
\hline & GSH conc. & $0.116 \pm 0.02$ & $0.119 \pm 0.004$ & $0.118 \pm 0.004$ & $\begin{array}{r}0.077 \pm 0.006 \\
\mathrm{Abc}\end{array}$ \\
\hline \multirow{3}{*}{$\begin{array}{l}\text { Four } \\
\text { weeks }\end{array}$} & $\begin{array}{l}\text { Testosterone } \\
\text { conc. }\end{array}$ & $6.0 \pm 0.3$ & $5.6 \pm 2$ & $8.8 \pm 2$ & $\begin{array}{r}1.6 \pm 0.7 \\
\mathrm{a} \mathrm{B} \mathrm{c}\end{array}$ \\
\hline & $\begin{array}{l}\text { Lipid peroxide } \\
\text { conc. }\end{array}$ & $13 \pm 0.6$ & $21.6 \pm 4$ & $14 \pm 3$ & $\begin{array}{r}29.4 \pm 1 \\
\mathrm{~A}\end{array}$ \\
\hline & GSH conc.) & $0.158 \pm 0.01$ & $0.158 \pm 0.01$ & $0.152 \pm 0.04$ & $\begin{array}{r}0.142 \pm 0.01 \\
\mathrm{Abc}\end{array}$ \\
\hline \multirow{3}{*}{$\begin{array}{c}\text { Six } \\
\text { weeks }\end{array}$} & $\begin{array}{l}\text { Testosterone } \\
\text { conc. }\end{array}$ & $8.1 \pm 2$ & $8.4 \pm 3$ & $8.8 \pm 2$ & $\begin{array}{r}1.6 \pm 0.7 \\
\mathrm{~A} \mathrm{~b} \mathrm{c}\end{array}$ \\
\hline & $\begin{array}{l}\text { Lipid peroxide } \\
\text { conc. }\end{array}$ & $11 \pm 3.7$ & $15 \pm 3$ & $16 \pm 4.8$ & $13.4 \pm 2.8$ \\
\hline & GSH conc. & $0.185 \pm 0.02$ & $\begin{array}{r}0.146 \pm 0.02 \\
\mathrm{a} \\
\end{array}$ & $\begin{array}{r}0.167 \pm 0.007 \\
\mathrm{a} \\
\end{array}$ & $\begin{array}{r}0.142 \pm 0.02 \\
\mathrm{Abc}\end{array}$ \\
\hline \multirow{3}{*}{$\begin{array}{l}\text { Eight } \\
\text { week }\end{array}$} & $\begin{array}{l}\text { Testosterone } \\
\text { conc. }\end{array}$ & $9.7 \pm 2.3$ & $9.6 \pm 1.3$ & $11.0 \pm 1.9$ & $7.6 \pm 2.2$ \\
\hline & $\begin{array}{l}\text { Lipid peroxide } \\
\text { conc. }\end{array}$ & $33 \pm 0.1$ & $36.3 \pm 3$ & $31 \pm 3.5$ & $38 \pm 5$ \\
\hline & GSH conc. & $0.160 \pm 0.008$ & $\begin{array}{r}0.145 \pm 0.003 \\
\mathrm{a} \\
\end{array}$ & $\begin{array}{r}0.127 \pm 0.01 \\
\mathrm{a}\end{array}$ & $\begin{array}{r}0.126 \pm 0.007 \\
\mathrm{Ab}\end{array}$ \\
\hline \multirow{3}{*}{$\begin{array}{c}\text { Ten } \\
\text { weeks }\end{array}$} & $\begin{array}{l}\text { Testosterone } \\
\text { conc. }\end{array}$ & $10.0 \pm 1.3$ & $9.2 \pm 1$ & $7.3 \pm 3.5$ & $\begin{array}{r}4.0 \pm 2 \\
\mathrm{~A} \mathrm{~b} \\
\end{array}$ \\
\hline & $\begin{array}{l}\text { Lipid peroxide } \\
\text { conc. }\end{array}$ & $27 \pm 2.6$ & $53 \pm 9$ & $43 \pm 3.5$ & $40 \pm 6$ \\
\hline & GSH conc. & $0.140 \pm 0.005$ & $\begin{array}{r}0.110 \pm 0.02 \\
\mathrm{a}\end{array}$ & $\begin{array}{r}0.100 \pm 0.01 \\
\mathrm{a}\end{array}$ & $\begin{array}{r}0.100 \pm 0.002 \\
\mathrm{~A}\end{array}$ \\
\hline \multirow{3}{*}{$\begin{array}{l}\text { Twelve } \\
\text { weeks }\end{array}$} & $\begin{array}{l}\text { Testosterone } \\
\text { conc. }\end{array}$ & $11.3 \pm 1$ & $10.8 \pm 0.7$ & $10.4 \pm 1.6$ & $\begin{array}{r}6.8 \pm 0.98 \\
\mathrm{~A}\end{array}$ \\
\hline & $\begin{array}{l}\text { Lipid peroxide } \\
\text { conc. }\end{array}$ & $30 \pm 6.9$ & $41 \pm 4$ & $44.4 \pm 1.5$ & $\begin{array}{r}50.2 \pm 3 \\
\mathrm{~A}\end{array}$ \\
\hline & GSH conc. & $0.169 \pm 0.002$ & $\begin{array}{r}0.133 \pm 0.01 \\
\mathrm{a}\end{array}$ & $\begin{array}{r}0.131 \pm 0.01 \\
\mathrm{a}\end{array}$ & $\begin{array}{r}0.130 \pm 0.006 \\
\mathrm{~A}\end{array}$ \\
\hline
\end{tabular}

For Testosterone concentration LSD at $\mathrm{P}<0.05$ is 3.571 , at $\mathrm{P}<0.01$ is 4.869

For Lipid peroxide concentration LSD at $\mathrm{P}<0.05$ is 16.355 , at $\mathrm{P}<0.01$ is 22.305

For GSH concentration LSD at $\mathrm{P}<0.05$ is .003446 , at $\mathrm{P}<0.01$ is .004701 


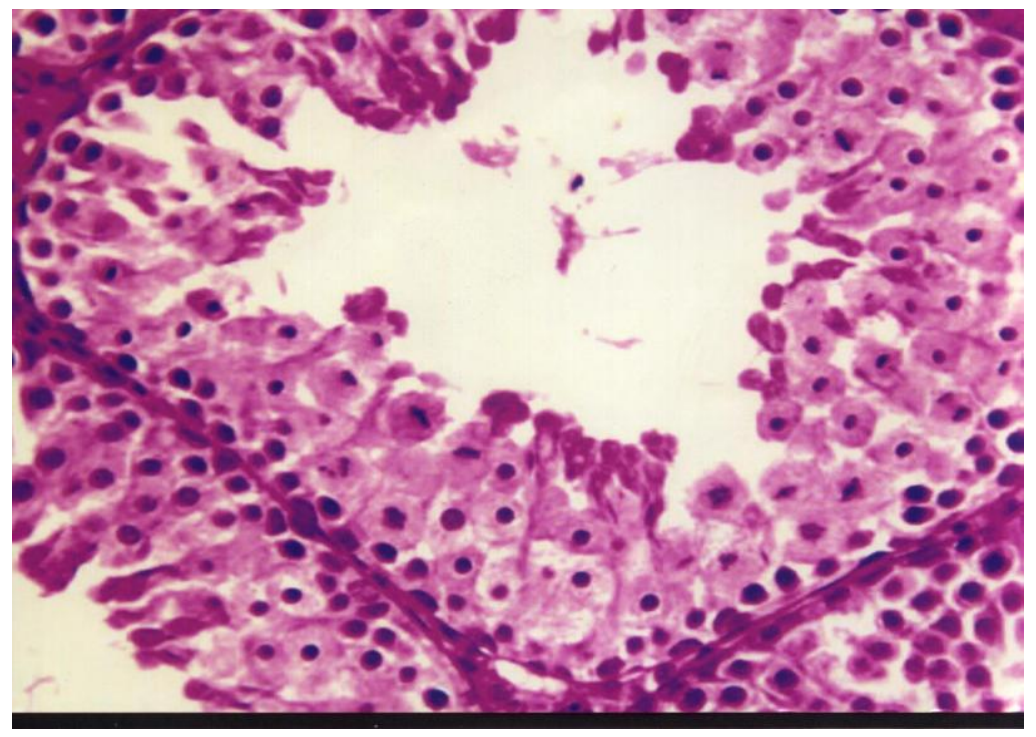

Fig. 1: Testis of rat treated with Katron (two weeks post-exposure) showing early degenerative changes in most spermatogonial cells (H\&E - X400).

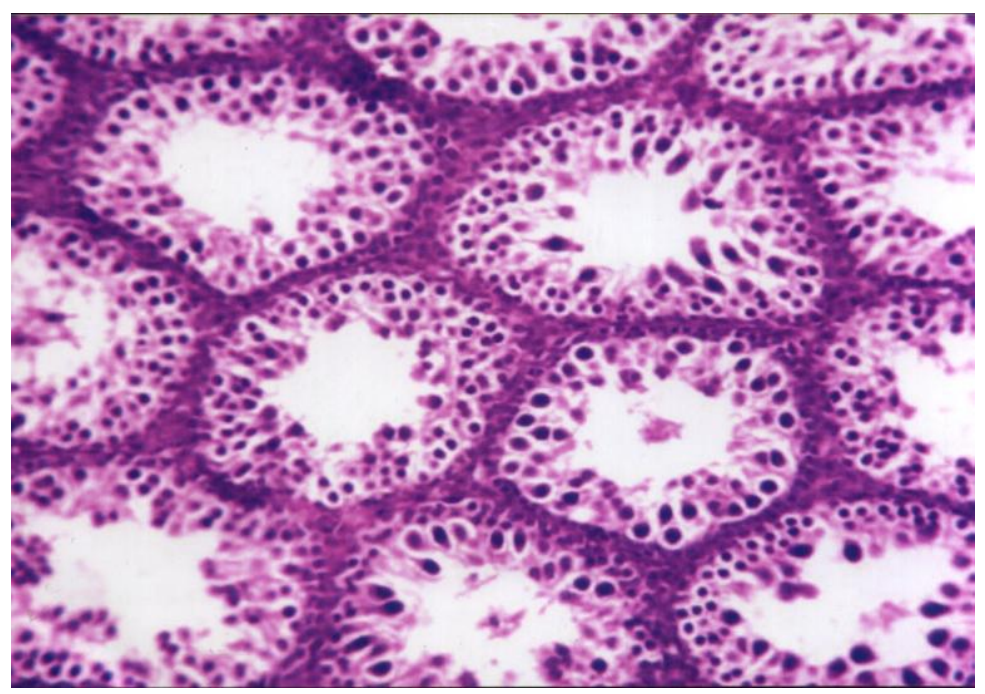

Fig. 2: Testis of rat treated with Katron (four weeks post- exposure) showing mild degenerative changes of spermatogonial cells (H\&E X 200). 


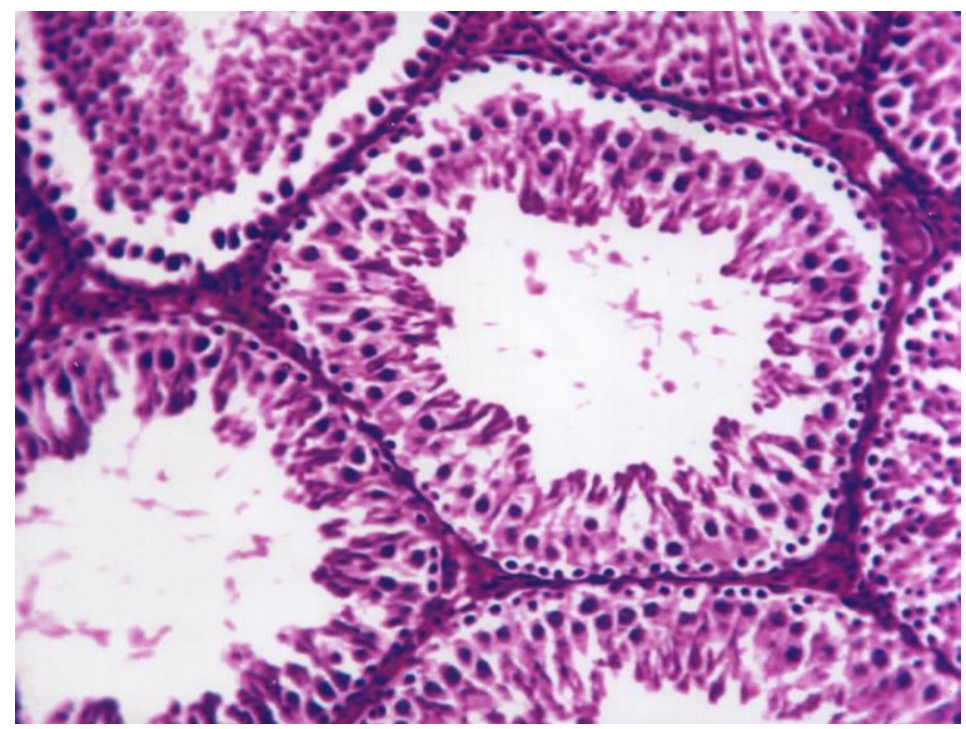

Fig. 3: Testis of rat treated with Katron and sodium fluoride (four weeks post-exposure) showing moderate to severe degree of degenerative changes (H\&E - X 200).

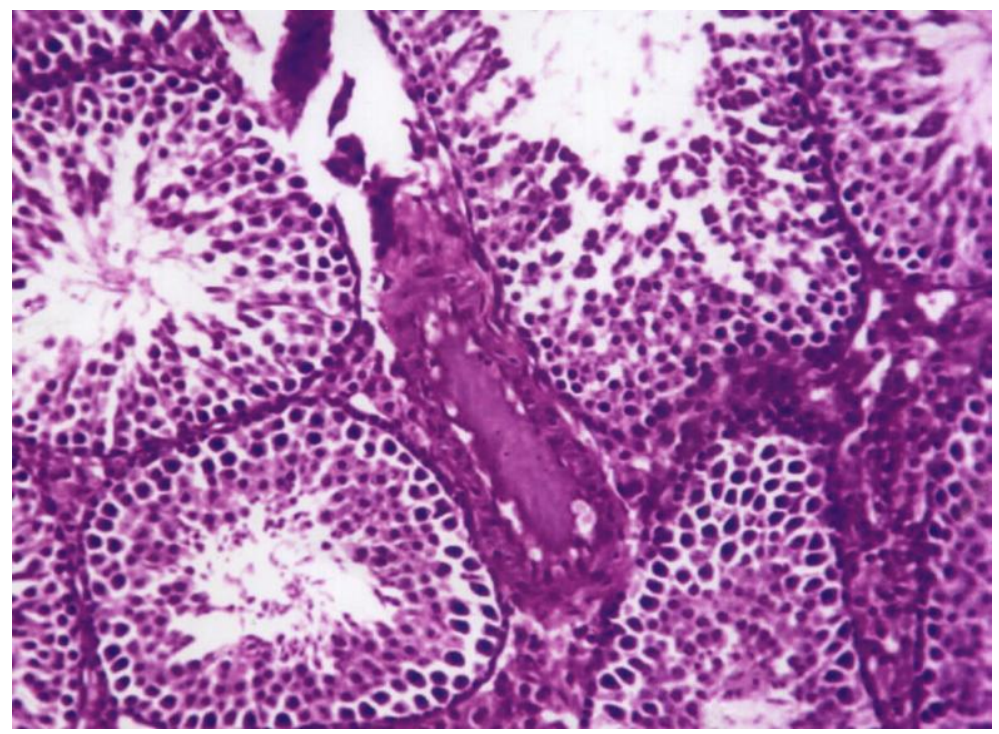

Fig. 4: Testis of rat treated with Katron and sodium fluoride (six weeks post-exposure) showing degenerative changes in the semineferous tubules, the leydig cells were profilated $(\mathrm{H} \& \mathrm{E}-$ X 200). 


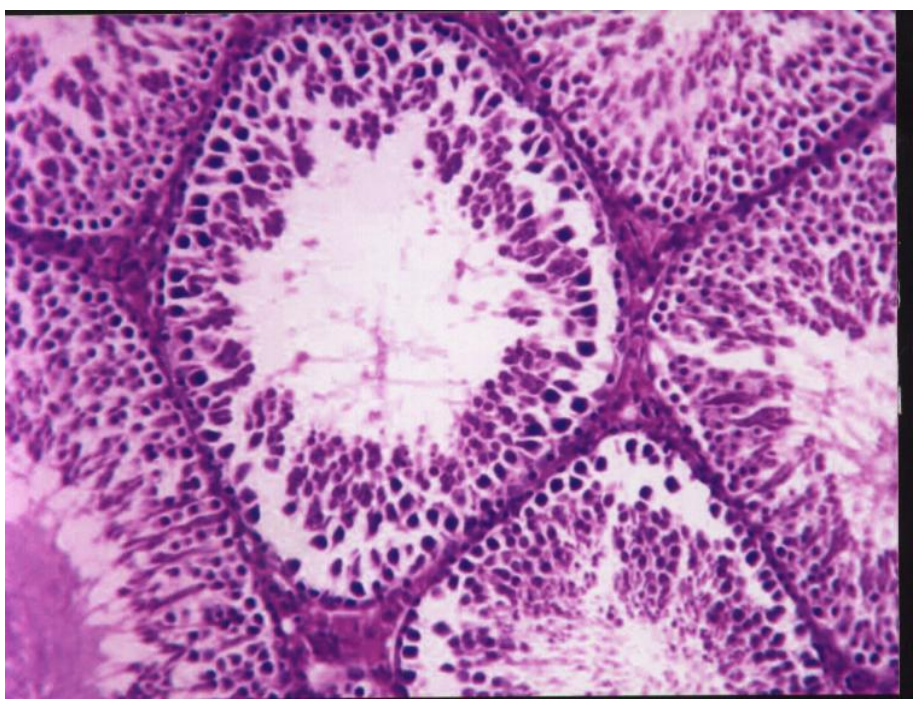

Fig. 5: Testis of rat treated with Katron and sodium fluoride (eight weeks post-exposure) showing sever degenerative changes and necrosis were seen in the semineferous tubules (H\&E - X 200).

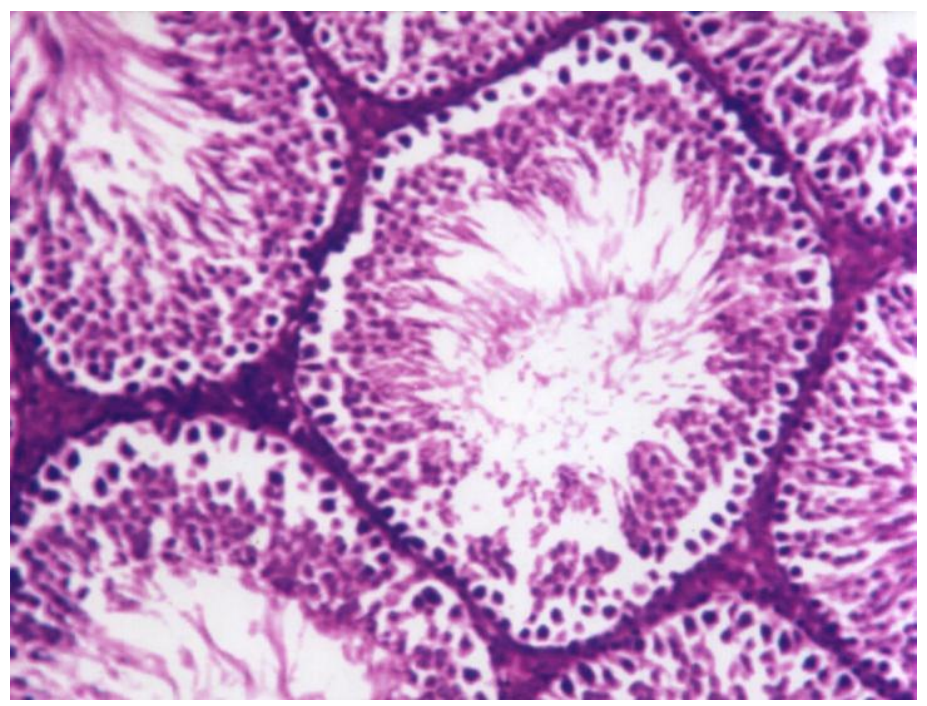

Fig. 6: Testis of rat treated with sodium fluoride (twelve weeks postexposure) showing very mild degenerative changes in the semineferous tubules (H\&E - X 200). 


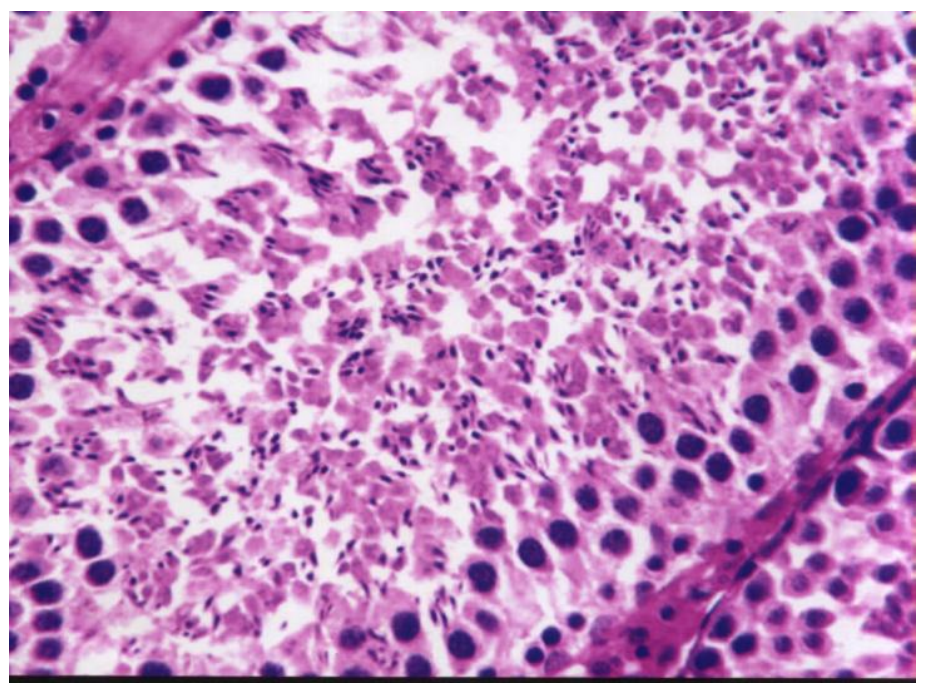

Fig. 7: Testis of rat treated with Katron and sodium fluoride (twelve weeks post-exposure) showing degenerative and dead sperm $(\mathrm{H} \& \mathrm{E}-\mathrm{X} 400)$.

\section{DISCUSSION}

The effect of two chemicals given semiltenousely will produce a response that may be simply additive of their individual response or may be greater or less than that expected by addition of their individual responses. Study of these interactions often leads to better understanding of the mechanism of action of the chemical involved (Doull et al., 1980).

A synergistic reaction between two chemicals occurs when both chemicals produce the toxicity of interest, and when combined, the presence of both chemicals cause a greater than additive effect (Phillip et al., 2000).

In view of these information, this study was undertaken to investigate mainly the toxic interaction between Lambada cyhalothrine (Katron) a widely used pyrethroid and sodium fluoride as one of water pollutants and their effects on male fertility of immature rats.

In the present study, results revealed that there is a significant reduction in the sperm motility from $6^{\text {th }}$ week till the end of the experiment in all treated groups (Group II, III and IV) in comparison with control (Group I) but this inhibition in sperm motility was more prominent in group IV which exposed to both Katron $(8 \mathrm{mg} / \mathrm{kg}$ b.wt. by intubation) and sodium fluoride $(150 \mathrm{mg} / \mathrm{L}$ in drinking water) for three months. Our results are consistent with the previous studies of Menha et al. (1999) who gave mature male rats aqueous suspension of 
Cypermethrin in oral dose equal to 7.7 and $3.8 \mathrm{mg} / \mathrm{kg}$ b.wt. for 65 successive days, there results showed an inhibition in the sperm motility. Low sperm motility were also reported by Narayana and Chinoy, (1994) as a result of administration of $10 \mathrm{mg} / \mathrm{kg}$ b.wt. sodium fluoride to male albino rat for 50 days by intubation. The decline in the sperm motility may be attributed to the loss of membrane permeability by the action of sodium fluoride which is considered as another major factor affecting the sperm motility (Chinoy, et al., 1995). At the same time Sugawara et al. (1986) reported that blood testes barrier (BTB) appeared to represent an important aspect in the consideration of reproductive effects of environmental chemicals. The inhibitory effect on sperm motility may be attributed to the reduction in meiotic index of the testicular cells which might be due to the passage of toxicant across the blood testes barrier (BTB) and gain access to the germ cells in seminiferous tubules.

The present results illustrated a significant decrease in sperm cell concentration in all treated groups (rats treated with Katron or sodium fluoride or both) but it is more pronounced in rats received both compound especially at the tenth and twelfth weeks post-exposure. Nearly similar finding to our data that were obtained by salem et al. (1996) who demonstrated that cypermethrin significantly decreased sperm motility, sperm cell concentration and percentage of live sperm and significantly increase incidence of sperm motilities compared with untreated controls Epididymal sperm count of male rat was decreased significantly after administration of sodium fluoride at a dose of 20 $\mathrm{mg} / \mathrm{kg} /$ day for 29 days by oral gavage as mentioned by Ghosh, et al. (2002). This significant decrease in sperm concentration may be attributed to the decrease in the testosterone levels, while the reduction in testosterone levels may be reduce the sperm cell counts by two mechanisms, the first through its direct effect on spermatogenesis and the second may be through elevation of super oxide anion and suppression of SOD activities (Purohit et al., 2000).

This study revealed that there is a significant decrease in the percentage of live sperm and significant increase in abnormalities $\%$ in all treated groups. This finding is correlated with those recorded by Hassan et al. (1993) who stated that there is a significant decrease in sperm cell count and significant increase in the abnormalities in male rats, after administration of sumicidin in doses of $20 \& 100 \mathrm{mg} / \mathrm{kg}$ b.wt. and S-3206 in doses of $1 \& 5 \mathrm{mg} / \mathrm{kg}$ b.wt. Both insecticides were administered daily for 65 successive days. Parallel to our result that recorded by Chinoy, (1991) who demonstrated that ingestion of sodium 
fluoride to mice, rats and rabbits induced decrease in the sperm density in cauda epididymis due to testicular spermatogenic arrest by the action of NaF . Also Chinoy, et al. (1995) mentioned that the evaluation of sodium fluoride treated spermatozoa with trypan blue showed a large number of dead sperm, probably due to loss of membrane permeability. The alteration in sperm motility, density and metabolism might be the outcome of the altered and hostile internal milieu of the epididymis of sodium fluoride treated rat since it is known that normal epididymal structure and its internal microenvironment are important for sperm maturation and for maintaining them in a viable, motile state as reported by Cooper (1986). Reduction in sperm motility has been related to inherited defects associated with sperm abnormalities (Au et al., 2001 b). In the same respect, fluorine as a metal has been shown to impair ATP production in mitochondria by diverting protons from phosphorylation (Kesseler and Brand, 1994). The observed mitochondrial disorganization, and hence inefficient ATP production, could explain the observed decreased in sperm motility in sea urchin exposed to metals (Au et al., 2000).

Results of histopathological examination of sexual organs explained the increased percentage of dead sperm (due to presence of degenerative changes and necrosis in the seminiferous tubules of testes and unmaturation of sperms).

The present investigations denoted that there is a significant decrease of serum testosterone level in all treated groups but it is extremely reduced in group IV (combination group), at the same time the testosterone concentration in testicular homogenate are reduced only in group IV. These findings were consistent with results of several investigators which revealed marked decrease in serum testosterone levels after administration of different synthetic pyrethroids, Menha et al. (1999) and Abd-El-Khaleh et al. (1999).

Abd-El-Aziz et al. (1994) mentioned that administration of deltamethrin in oral dose of $1 \mathrm{mg} / \mathrm{kg} /$ day exhibited significant reduction of plasma testosterone levels in treated rats. On the other hand Kanwar, et al. (1983) stated there is a marked fall in the testosterone production in rats at a fluoride concentration of $100 \mathrm{ppm}$ and testosterone synthesis was maximally inhibited at $200 \mathrm{ppm}$ and though marginal, inhibition in testosterone synthesis even at $10 \mathrm{ppm}$ fluoride concentration. Exposure to $250 \mathrm{uM}$ fluoride inhibits testosterone secretion by rat testes perfused in vitro as reported by Chubb (1985). Also Araibi et al. (1989) mentioned that administration of sodium fluoride ( 5 or $10 \mathrm{mg} / \mathrm{kg} / \mathrm{day}$ ) 
for 60 days to male rats resulted in decreased testosterone levels. The significant reduction in testosterone levels may be attributed to the direct toxic effect on leydig cells or may be due to fluctuation in the level of LH which stimulates testosterone secretion by leydig cells as mentioned by Sobhy (1991) and Hassan et al. (1993).

The results in the current study emphasized that levels of lipid peroxidation in serum and testicular homogenate were increased significantly in group IV only (which exposed to both Katron and sodium fluoride). Glutathione concentration was reduced in group II (which gavaged with Katron) and group III (which administered sodium fluoride in drinking water) only at the end of experiment, while it was reduced along the period of experiment in group IV (combination group). At the same time the activity of super- oxide dismutase was reduced in all treated groups at the last six weeks of experiment. Similarly Manisha et al. (1999) mentioned that male wister rat treated with single dose of $0.001 \% \mathrm{LD}_{50}$ of cypermethrin and/or fenvalerate orally increased lipid peroxidation in tissues and decrease in R-GSH activity, so pyrethroid intoxication alter the antioxidant system by inducing lipid peroxidation, elevation of lipid peroxidation in testes tissue may be attributed to generation of reactive oxygen species (ROS) during pyrethroid metabolism, the elevation of lipid peroxidation on pyrethroid intoxication alters the antioxidant system .

Soni et al. (1984) recorded that administration of $20 \mathrm{mg} / \mathrm{kg}$ sodium fluoride increased lipid peroxidation levels in testes. Also Zhang et al. (2000) mentioned that there was decrease in the activity of glutathione reduced and superoxide dismutase in the blood with increase of lipid peroxides concentration after exposure of rats to ascending doses of $\mathrm{NaF}$. The effect of sod. fluoride on the level of lipid peroxidation, glutathione concentration and the activity of super- oxide dismutase may attributed to that mentioned by (Ercal et al., 2001) who stated that metals increase production of reactive oxygen species (ROS) such as hydroxyl radical (OH.), superoxide radical (O2.-) or hydrogen peroxide (H2O2). Enhanced generation of ROS can overwhelm cells intrinsic antioxidant defenses, and result in a condition known as "oxidative stress" with increase the level of lipid peroxidation and reduction of antioxidant enzymes including reduced glutathione and superoxide dismutase enzymes. Cells under oxidative stress display various dysfunctions due to lesions caused by ROS to lipids, proteins and DNA. Consequently, it is suggested that metal-induced oxidative stress in cells can be partially responsible for the toxic effects of heavy metals. 
Megahed et al. (2001) reported that there are a relation between testosterone levels and antioxidant system in spermatozoa and epididymal fluid where reduction in testosterone level may be potentiate the elevation of free oxygen radical, that increase lipid peroxidation which alter glutathione content, oxidative stress not only affected seminiferous tubules and epididymal spermatozoa but also it affect the number and viability of leydig cell which reflected by decreased levels of testosterone. Myers and Abney (1988) found a reduction in testosterone synthesis in leydig cell culture as a results to elevation of free radicals. Also Muller et al. (1998) mentioned there is a close relation ship between testicular MDA levels and reduction in testosterone synthesis. Mammalian testes and spermatozoa are rich in poly unsaturated fatty acids (PUFA) which are the main targets of free radical damage and sensitive to oxygen induced damage mediated by lipid peroxidation as mentioned by Sikka (1996). Also Sikka et al. (1995) investigated that increased free oxygen suppress functions spermatozoa and reduce their survival, in relation to the significant elevation of lipid peroxidation and reduction of glutathione.

The histopathological changes obtained in the present study confirm study data. Moderate to severe degree of degenerative changes could be observed in a large number of the testicular tubules with incomplete spermatogenic process, the basement membrane appeared thickened and leydig cells were proliferated. These changes are more prominent in rats that exposed to both Katron and sodium fluoride than those administered Katron or sodium fluoride alone.

The study results are in agreement with Menha et al. (1999) who recorded the effect of Cypermethrin in adose of 7.7 and $3.8 \mathrm{mg} / \mathrm{kg}$ for successive 65 days on testes, where they showed inactivation of the semineferous tubules with incomplete spermatogenesis in most of them, also seminal vesicle and prostate glands showing polyp formation. Also Fatma et al. (1996) reported that pyrethroid cause severe degenerative changes in the semineferous tubules, so the tubules are lined by a layer of Sertoli cells, then the degeneration increase to cause severe hypoplasia and complete necrosis. On the other side Araibi, et al. (1989) mentioned that administration of 100 or $200 \mathrm{ppm} \mathrm{NaF}$ (5 or $10 \mathrm{mg}$ fluoride $/ \mathrm{kg} / \mathrm{day}$ ) for 60 days to male rats resulted in decrease percentage of seminiferous tubules containing spermatozoa with significant increase in the thickness of the peritubular membrane of the seminiferous tubules.

Sun, et al. (1990) found that clear desquamation of normal intact spermatocyte in the lumen was observed in testes subjected to different 
toxic chemicals or may be due to persistent decrease in FSH level. The detachment of degenerated cells in addition to desquamation of intact spermatocyte may lead to epithelial disorganization and missing of semineferous epithelium, this may be due to inhibition of microtubule formation in Sertoli cells and mitotic division of germ cells as seen by Russell, et al. (1981) or direct effect of toxicants on Sertoli cell function as reported by Hess, et al. (1991).

In Conclusion great attention should be taken during Lambda cyhalothrine (Katron) field application in the presence of sodium fluoride as water pollutant, to avoid possible adverse reproductive effects in farm animals and occupationally exposed human, where there is a synergistic effect between these two compounds on male fertility especially when exposure beginning in young ages before maturity.

\section{REFERENCES}

Abd El Aziz, M.A.; Sahlab, A.M.; Abdel Khalik, M. and Aziz, M.I. (1994): Influence of diazinone and deltamethrine on reproductive organs and fertility of male rats. Deutsche Tierarztlich Wochenschrift 101-106., 230-32.

Abd El Khalek, M.M.; Rahmy, N.A. and Halem, H.H. (1999): Effect of the pyrethroid insecticide cypermethrin on fertility in male rats. Veterinary Medical Journal Giza, 47: 3, 295-305.

Araibi, A.A.; Yousif, W.H. and Al-Dewachi, O.S. (1989): Effect of highfluoride on the reproductive performance of the male rat. J. Biol. Sci. Res; 20 (1). 1989. 19-30.

Au, D.W.T.; Chiang, M.W.L. and Wu, R.S.S. (2000): Effects of cadmium and phenol on motility and ultra structure of sea urchin and green mussel sperm. Archives of Environmental Contamination and Toxicol., 38: 455-63.

Au, D.W.T.; Reunov, A.A. and Wu, R.S.S. (2001b): Reproductive impairment of sea urchins upon chronic exposure of cadmium. Part: II Effects on sperm development. Environmental pollution, 111: 11-20.

Bearden, J.H. and Fuquay, J.W. (1980): Applied animal reproduction. Rston publishing co., Inc. Restan. Virginia.

Beutler, E.; Dueren, C. and Kelly, B.M. (1963): Improved method for the determination of glutathione. J. Lab. And Clin. Med. 61: 882-88.

Blom, E. (1950): A simple rapid staining method for the differentiation between live and dead sperm cells by means of eosin and nigrosine stain. Nord. Vet. Med., 2: 58. 
Carleton, M.A.; Drury, R.A.; Willington, E.A. and Cameron, H. (1967): Carleton histopathological techniques. $4^{\text {th }}$ Ed. Oxford.Univ. Press. New York.

Chinoy, N.J. (1991): Effects of fluoride on physiology of some animals and Human being. Indian Journal of Environ. and Toxicol. 1 (1) 17-32.

Chinoy, N.J.; Narayana, M.V.; Dalal,V.; Rawat, M. and Patel, D. (1995): Amelioration of fluoride toxicity in some accessory reproductive glands and spermatozoa of rat. Fluoride 1995; 28(2): 75-86.

Chubb, C. (1985): Reproductive toxicology of fluoride 3rd International Congress of Andrology, Boston, Massachusetts. J. Androl 6: 59 (1985).

Cooper, T.G. (1986): The epididymal sperm maturation and fertilization. Springer-Verlag, New York p. 281.

Doull, M.D.; Klassen,D. and Andur, O. (1980): The basic signs of poisons, $2^{\text {nd }}$ edition. New york.

Ercal, N; Gurer-Orhan, H. and Aykin-Burns, N. (2001): Toxic metals and oxidative stress part I: mechanisms involved in metalinduced oxidative damage. Curr Top Med Chem, 1(6): 529-39.

Farzana, P. (2004): Environmental pollution in Sindh, Pakistan. Understanding environmental pollution, Williams and Wilkins, $2^{\text {nd }}$ edition.

Fatma, M.S.; Galila, A.; El-Mansoury, H.A. and Hanan, E. (1996): Reproductive performance in rats and ewes treated with pyrethroids (Ectomin). Assiut Vet. Med. J. Vol. 34 No. 68. Jan.

Ghosh, D.; Das(Sarkar), S.; Maiti, R.; Jana, D. and Das (2002):

Testicular toxicity in sodium fluoride treated rats: association with oxidative stress. Reprod Toxicol 2002 Jul; 16(4): 385.

Hassan, A.B.; Soliman, G.A.; Farag, A.A. and Hanan, M. (1993): Effect of the synthetic pyrethroids sumicidin and s-3206 0n male rat fertility. Vet. Med. J., Giza. Vol.41, No.2: 33-38.

Hess, R.A; Moor, B.J.; Forer, J.; Linder, R.E. and Abuel Atta, A.A. (1991): The Benomyel (Methyle- Butyl- Carbamosyl- 2Benzimidazole) causes testicular dysfunction by inducing the sloughing of germ cells and occlusion of efferent ductules. Fundamental and applied toxicology, 17 (4): 733-45.

Kanwar, K.C.; Vig, P.S. and Kalla, N.R. (1983): In vitro inhibition of testosterone synthesis in the presence of fluoride ions IRCS Med. Sci. 11, 813-14. 
Kesseler, A. and Brand, M.D. (1994): Localisation of the sites of action of cadmium on oxidative phosphorylation on potato tuber mitochondria using top-down elasticity analysis. European Journal of Biochemistry, 225: 897-906.

Manisha, KK.; Nisha, R.; Susan, J.; Deepak, B.; Kale, M.; Rathore, N.; Jhon, S. and Bahatnagar, D. (1999): Lipid peroxidation and antioxidant enzymes in rat tissues in pyrethriod toxicity. Possible involvement of reactive oxygen species. J. of Nutritional and environmental Medicine. 9: 1, 37-46.

Megahed, G.A.; Anwar, M.M. and Madeha, M. (2001): The effect of Aluminum pollution on the male reproductive system in rats. Role of oxyradicals. Assiut Vet. Med. J. Vol. 45 No. 90.

Menha, M.A.; Nariman, A. and Haleem, H.H. (1999): Effect of the pyrethroid insecticide cypermethrin on fertility in male rats.Vet. Med. J., Giza. Vol. 47, No. 3: 295-305.

Misra, H.P. and Fridouich, I. (1972): The role of epinephrine and a simple assay for superoxide dismutase. J. Biol. Chem. 247: 3170- 75.

Muller, A.; Hermo, L. and Robaire, B. (1998): The effect of aging on the expression of glutathione s- transeferase in the testes and epididymis of the Brown Norway rat. J. Androl., 19: 450-65.

Myers, R.R. and Abney, T.O. (1988): The effects of reduced $\mathrm{O}_{2}$ and antioxidants on steroidogenic capacity of cultured rat leydig cells. J. Steroid. Biochem., 31: 305-9.

Narayana, M.V. and Chinoy, N.J. (1994): Effect of fluoride on rat testicular steroidogenesis. Fluoride 1994; 27(1): 7-12.

Phillip, L.W.; Ropert, C.J. and Stephen, M.R. (2000): Principles of toxicology. Environmental and industrial applications. $2^{\text {nd }}$ edition. Copyright by John Wiley \& Sons, Inc. Library of congress.

Purohit, S.B.; Saxena, D.; Laloraya,M. and Kumar, G.P. (2000): Altered molecular dynamics and antioxidant status in the spermatozoa in testosterone induced oligospermia in mouse. Mol. Reprod. Dev. 55: 316-25.

Russell, L.D.; Malon, J.P. and Mac Curdy, D.S. (1981): Effect of the microtubule disrupting agents, colchicines and vinblastino, on semineferous tubules structure in rat tissue. Cell.13, 349-67.

Salem, F.M.; EL-Rafey, G.A.; EL Mansoury, H.A. and youssef, A.E. (1996): Reproductive performance in rats and ewes treated 
with pyrethroid (Ectomin). Assiut, Veterinary Medical Journal. 34: $68,103-23$.

Salem, D.A.; Abdou, K.A. and Zaky, Z.M. (2001): Estimation of some Chemical pollutants in drinking and surface water in upper Egypt. Assiut University Bulletin for Environmental Researches, Vol. 4 No. 1, March.

Sendecor, G.W. and Cochran, W.G. (1982): Statistical methods, $6^{\text {th }}$ Edition Iowa Univ. Press, Ames, U.S.A.

Sikka, S.C.; Rajasekaran, M. and Hellstrom, W.J. (1995): Role of oxidative stress and antioxidants on male fertility. J. Androl., 16: 464-545.

Sikka, S. (1996): Oxidative stress and role of antioxidants in normal and abnormal sperm function from tiers in Bioscience, 1: 78-86.

Sobhy, H.M. (1991): Effect of Sumicidin and S-3206 insecticides (synthetic pyrethroids) on fetal development and male fertility in rats. Ph.D thesis (Pharmacology) Cairo Univ.

Soni, M.G.; Kachole, M.S. and Pawar, S.S. (1984): Alterations in drug metabolising enzymes and lipid peroxidation in different rat tissues by fluoride. Toxicol Lett 1984 May; 21(2):167-72.

Sugawara, N.; Hirhata, Y. and Sugawara, V. (1986): Testicular dysfunction induced by cadmium and its important caused by selenium in mouse. J. Environ. Path. Toxicol. 9: 1, 53-64.

Sun, Y.; Wreford, N.G.; Robertson, D.M. and Dekrester, D.M. (1990): Quantitative cytological studies of spermatogenesis in the intact and hypophysectomized rats: Identification of androgendependent stages. Endocrinology 127/3: 1215-22.

Thyer, W.S. (1985): Serum Lipid Peroxide in rats treated chronically with adiramycin. Biochem. Pharmacol., 33 : 2259-63.

Voller, A.; Bidwell, D.E. and Bartellet, A. (1979): The Enzyme Linked Immunosorbant Assay ELISA. The Zoological Society of London, pp.16-17.

WHO (World Health Organization) (1990): Cyhalothrine environmental health. Criterin, 99: Switherland.

Zhang, C.; Liu, B.; Song, X.; Gu, W. and Wang, G. (2000): The effect of fluoride -Arsenic exposure on the lipid peroxidation and antioxidation of rats. Zhonghua Yu Fang Yi Xue Za Zhi. May; 34 (3): 134-5.

Zhu, X.Z.; Ying, C.J.; Liu, S.H.; Yang, K.D. and Wang, Q.Z. (2000): The primary study of antagonism of selenium on fluoride-induced reproductive toxicity of male rat. Chung-Kuo Kung Kung Wei 
Assiut Vet. Med. J. Vol. 54 No. 119 October 2008

Sheng (China Public Health) 2000 Aug; 16(8): 697-8. 